\title{
ANALISIS PENGARUH TATO, WCTO, DAN DER TERHADAP NILAI PERUSAHAAN DENGAN ROA SEBAGAI VARIABEL INTERVENING (Studi pada Perusahaan Manufaktur yang Terdaftar di Bursa Efek Indonesia Periode Tahun 2009-2013)
}

\author{
Rahmawati Budi Utami*, Prasetiono ${ }^{1}$ \\ rahmatami17@gmail.com \\ Jurusan Manajemen Fakultas Ekonomika dan Bisnis Universitas Diponegoro \\ Jl. Prof. Soedharto SH Tembalang, Semarang 50239, Phone: +622476486851
}

\begin{abstract}
The aims of this research is to examine the direct effect and indirect effect of Total Asset Turnover, Working Capital Turnover, Debt to Equity Ratio on Firm Value with Return On Asset as an intervening variable.

This research sample is manufacturing companies listed in the Indonesia Stock Exchange (IDX) period 2009-2013 by using purposive sampling method. There are 64 manufacturing companies selected as sample. The method of analysis used is Path Analysis, the development of multiple linear regression.

Using multiple regression analysis, it is known that TATO has positive significant effect on ROA. WCTO and DER has negative significant effect on ROA. TATO has positive not significant effect on Firm Value. WCTO has negative significant effect on Firm Value. DER and ROA has positive significant effect on Firm Value. The result of path analysis showed that TATO influence Firm Value through ROA. Besides, it was found that the value of the adjusted $R$ square for the equation ROA is 25,3\% while the value of the adjusted $R$ square for the equation PBV is $39,7 \%$.
\end{abstract}

Keywords: Total Asset Turnover (TATO), Working Capital Turnover (WCTO), Debt to Equity Ratio (DER), Return On Asset (ROA), Firm Value

\section{PENDAHULUAN}

Perusahaan (firm) adalah suatu organisasi yang mengombinasikan dan mengorganisasikan berbagai sumber daya dengan tujuan untuk memproduksi barang dan/atau jasa untuk dijual. Tujuan utama berdirinya perusahaan yaitu memperoleh profitabilitas, memaksimalkan laba atau kekayaan, dan memaksimalkan nilai perusahaan (Scott dalam Agustina, 2014). Menurut theory of the firm, tujuan utama perusahaan adalah untuk memaksimalkan nilai perusahaan (value of the firm) (Salvatore, 2005). Salah satu faktor yang mempengaruhi tinggi rendahnya nilai perusahaan adalah kinerja keuangan suatu perusahaan. Perusahaan dengan kinerja keuangan yang baik akan menghasilkan laba yang maksimal sehingga dapat memberikan pengembalian investasi yang tinggi. Dengan demikian, meningkatnya nilai perusahaan ditandai dengan tingginya harga saham perusahaan tersebut (Weston dan Copeland, 1999).

Baik atau buruknya kinerja perusahaan dapat dilihat dari seberapa besar profitabilitas yang berhasil dicapai perusahaan tersebut. Profitabilitas dapat 
dijadikan tolak ukur tentang seberapa efektif kinerja manajemen dilihat dari keuntungan yang diperoleh dibandingkan dengan hasil penjualan dan investasi perusahaan. Return On Asset merupakan rasio antara laba setelah pajak dengan total aktiva. Jika ROA meningkat, berarti meningkat pula profitabilitas perusahaan dan hasil akhirnya adalah semakin besarnya tingkat kembalian (return) untuk para pemegang saham (Husnan, 2002).

Profitabilitas dan nilai perusahaan dipengaruhi oleh beberapa faktor. Total Asset Turnover merupakan rasio untuk mengukur efektivitas penggunaan seluruh aktiva dalam menghasilkan penjualan (Sudana, 2011). Semakin besar TATO menunjukkan semakin efisien penggunaan seluruh aktiva perusahaan dalam menunjang kegiatan penjualan. Working Capital Turnover menunjukkan perputaran modal kerja saat perusahaan menginvestasikan kas dalam beberapa komponen modal kerja yang dibutuhkan sampai kembali menjadi kas. Debt to Equity Ratio mencerminkan tingkat penggunaan hutang terhadap total ekuitas (Sudana, 2011). Semakin besar tingkat hutang yang dimiliki perusahaan, semakin tinggi pula risiko kredit yang ditanggung perusahaan.

Besarnya rata-rata TATO, WCTO, DER, ROA, dan PBV pada perusahaan manufaktur yang tercatat di BEI periode 2009-2013 disajikan sebagai berikut:

Tabel 1

Rata-rata TATO, WCTO, DER, ROA, dan PBV pada Perusahaan Manufaktur yang Tercatat di BEI Periode 2009-2013

\begin{tabular}{lccccc}
\hline \multicolumn{1}{c}{ Rasio } & $\mathbf{2 0 0 9}$ & $\mathbf{2 0 1 0}$ & $\mathbf{2 0 1 1}$ & $\mathbf{2 0 1 2}$ & $\mathbf{2 0 1 3}$ \\
\hline TATO (x) & 1,30 & 1,32 & 1,35 & 1,30 & 1,25 \\
WCTO (x) & 6,84 & 7,15 & 5,99 & 7,04 & 7,21 \\
DER (x) & 0,86 & 0,82 & 0,78 & 0,75 & 0,85 \\
ROA (\%) & 9,89 & 11,45 & 11,40 & 11,76 & 9,77 \\
PBV (x) & 1,87 & 2,50 & 2,52 & 2,61 & 2,55 \\
\hline
\end{tabular}

Sumber: ICMD

Tabel 1 menunjukkan adanya hubungan yang tidak konsisten antara nilai rata-rata Total Asset Turnover (TATO), Working Capital Turnover (WCTO), Debt to Equity Ratio (DER), Return On Asset (ROA), dan Price to Book Value (PBV) pada perusahaan manufaktur yang terdaftar di Bursa Efek Indonesia periode 2009-2013. Profitabilitas yang diproksi dengan ROA mengalami penurunan pada tahun 2011 tetapi nilai perusahaan yang diproksikan dengan PBV justru mengalami peningkatan.

Total Asset Turnover mengalami peningkatan pada tahun 2011 sedangkan ROA mengalami penurunan. Lalu pada tahun 2012 TATO mengalami penurunan sedangkan ROA dan PBV mengalami peningkatan. Working
Capital Turnover mengalami penurunan pada tahun 2011 tetapi PBV justru meningkat. Lalu pada tahun 2013 WCTO mengalami peningkatan tetapi ROA dan PBV mengalami penurunan. Begitu pula dengan Debt to Equity Ratio yang mengalami penurunan pada tahun 2011dan ROA juga mengalami penurunan.

Penelitian terdahulu mengenai pengaruh TATO terhadap ROA menunjukkan hasil positif dikemukakan oleh Noor (2011), Alivia (2013), Sari (2013), dan Budiasih \& Ni (2014). Sedangkan hasil negatif dikemukakan oleh Sulistyawan (2005). Penelitian mengenai pengaruh WCTO terhadap ROA menunjukkan hasil positif dikemukakan oleh Nugroho (2010), Husaini, Difky, dan Darminto (2014) 
serta Utama (2014). Sedangkan Noor (2011) serta Arif, Raden, dan Zahroh (2015) menyatakan hasil negatif. Penelitian mengenai pengaruh DER terhadap ROA yang dikemukakan oleh Rahmawati (2012) menunjukkan hasil positif. Sedangkan Sari (2013), Budiasih \& Ni (2014), dan Utama (2014) menunjukkan hasil negatif.

Penelitian tentang pengaruh TATO terhadap nilai perusahaan oleh Alivia (2013) menunjukkan hasil positif. Sedangkan Ulupui (2007) menunjukkan hasil yang negatif. Penelitian mengenai pengaruh DER terhadap nilai perusahaan oleh Sari (2013) dan Marlina (2013) menyatakan hasil positif. Sedangkan hasil negatif ditunjukkan dalam penelitian Nasehah (2012) dan Erawati \& Sukma (2014). Penelitian oleh Ardimas (2012), Alivia (2013), dan Sari (2013) menyatakan bahwa ROA memiliki pengaruh positif terhadap nilai perusahaan. Sedangkan Carningsih (2012) menyatakan hasil yang negatif.

\section{KERANGKA} TEORITIS HIPOTESIS

\section{Pengaruh TATO terhadap ROA}

Total Asset Turnover mengukur kemampuan perputaran seluruh aset yang dimiliki perusahaan. Semakin besar nilai TATO berarti semakin efisien perusahaan menggunakan seluruh aset dalam menunjang kegiatan penjualan. Semakin efisien maka semakin baik pula kinerja perusahaan. Kinerja perusahaan yang baik akan dicerminkan kedalam nilai ROA yang baik pula. Dengan demikian dapat dirumuskan hipotesis sebagai berikut:

H1: Total Asset Turnover berpengaruh positif terhadap Return on Asset

\section{Pengaruh WCTO terhadap ROA}

Periode perputaran modal kerja (working capital turnover) dimulai saat kas diinvestasikan dalam komponenkomponen modal kerja sampai kembali lagi menjadi kas. Perusahaan akan menginvestasikan kas yang mereka miliki kedalam berbagai modal kerja, seperti bahan baku, tenaga kerja, dan BOP. Modal kerja tersebut akan diolah menjadi barang jadi dan menghasilkan penjualan sampai akhirnya kembali menjadi kas. Investasi perusahaan kedalam modal kerja tersebut diharapkan dapat memberikan penjualan yang baik sehingga dapat membantu meningkatkan profitabilitas perusahaan. Dengan demikian dapat dirumuskan hipotesis sebagai berikut:

$\mathrm{H} 2$ : Working Capital Turnover berpengaruh positif terhadap Return On Asset

\section{Pengaruh DER terhadap ROA}

Debt to Equity Ratio (DER) adalah rasio antara total hutang dengan total ekuitas. Nilai DER yang tinggi menunjukkan bahwa perusahaan menggunakan cukup banyak hutang untuk kegiatan operasional perusahaan. Hutang yang tinggi akan mempengaruhi laba bersih yang akan diterima perusahaan karena hutang yang tinggi akan memberikan beban bunga yang tinggi pula sehingga akan mengurangi laba bersih perusahaan. Semakin kecil laba bersih yang diperoleh perusahaan, akan semakin kecil pula ROA perusahaan. Dengan demikian dapat dirumuskan hipotesis sebagai berikut:

H3: Debt to Equity Ratio berpengaruh negatif terhadap Return On Asset

\section{Pengaruh TATO terhadap Nilai Perusahaan}

Tingginya nilai Total Asset Turnover menunjukkan semakin efektif penggunaan aktiva perusahaan dalam rangka memperoleh laba dari penjualan perusahaan. Semakin tinggi TATO menunjukkan bahwa pendayagunaan aset perusahaan dalam rangka memperoleh penjualan akan semakin tinggi. Tingginya pendayagunaan aset tersebut akan diapresiasi oleh pasar dengan semakin tingginya harga saham perusahaan. Dengan demikian dapat dirumuskan hipotesis sebagai berikut: 
H4: Total Asset Turnover berpengaruh positif terhadap nilai perusahaan

\section{Pengaruh WCTO terhadap Nilai Perusahaan}

Working Capital Turnover menggambarkan bagaimana perusahaan menginvestasikan kas yang mereka miliki kedalam komponen modal kerja sampai kembali lagi menjadi kas. Semakin cepat perputaran modal kerja menunjukkan perusahaan semakin efisien sehingga profitabilitas juga meningkat. Profitabilitas yang meningkat juga akan berdampak pada peningkatan harga saham. Dengan demikian dapat dirumuskan hipotesis sebagai berikut:

H5: Working Capital Turnover berpengaruh positif terhadap nilai perusahaan

\section{Pengaruh DER terhadap Nilai Perusahaan

Debt to Equity Ratio
menggambarkan perbandingan antara total hutang dengan total ekuitas yang dimiliki perusahaan. Meningkatnya DER berarti meningkat pula beban bunga yang ditanggung perusahaan. Dengan semakin meningkatnya DER mengakibatkan profitabilitas perusahaan mengalami penurunan. Penurunan profitabilitas akan berdampak terhadap penurunan harga saham perusahaan. Dengan demikian dapat dirumuskan hipotesis sebagai berikut:

H6: Debt to Equity Ratio berpengaruh negatif terhadap nilai perusahaan

\section{Pengaruh ROA terhadap Nilai} Perusahaan

$$
\text { Return On Asset (ROA) }
$$

merupakan rasio profitabilitas yang digunakan untuk mengukur kinerja keuangan perusahaan. Kinerja perusahaan yang baik ditunjukkan dengan peningkatan profitabilitas yang juga berarti prospek perusahaan yang semakin baik. Perusahaan dengan prospek yang baik menjadi daya tarik bagi investor karena dinilai akan memberikan kemakmuran yang tinggi bagi pemegang saham. Peningkatan ROA mampu meningkatkan nilai perusahaan. Sehingga semakin tinggi ROA akan semakin tinggi pula nilai perusahaan. Dengan demikian dapat dirumuskan hipotesis sebagai berikut:

H7: Return On Asset berpengaruh positif terhadap nilai perusahaan

ROA Memediasi Pengaruh TATO terhadap Nilai Perusahaan

Total Asset Turnover (TATO) mempunyai pengaruh positif terhadap profitabilitas yang diukur dengan Return On Asset (ROA) seperti penelitian yang dilakukan oleh Noor (2011), Alivia (2013) dan Sari (2013). Disamping itu TATO mempunyai pengaruh positif pula terhadap nilai perusahaan, sebagaimana penelitian yang dilakukan oleh Alivia (2013). Karena TATO berpengaruh positif terhadap ROA dan PBV, dengan demikian dapat dirumuskan hipotesis sebagai berikut:

H8: Return On Asset memediasi pengaruh TATO terhadap nilai perusahaan

\section{ROA Memediasi Pengaruh WCTO terhadap Nilai Perusahaan

Working Capital Turnover

(WCTO) mempunyai pengaruh positif terhadap profitabilitas yang diukur dengan Return On Asset (ROA) sebagaimana penelitian yang dilakukan oleh Husaini, Darminto, dan Difky (2014) dan Utama (2014). WCTO yang tinggi menunjukkan bahwa perusahaan menggunakan modal kerja dengan baik yang akan diapresiasi oleh pasar dengan semakin tingginya harga saham perusahaan. Dengan demikian dapat dirumuskan hipotesis sebagai berikut:

H9: Return On Asset memediasi pengaruh WCTO terhadap nilai perusahaan

ROA Memediasi Pengaruh DER terhadap Nilai Perusahaan

Debt to Equity Ratio (DER) mempunyai pengaruh negatif terhadap profitabilitas yang diukur dengan Return On Asset (ROA) seperti penelitian yang 
dilakukan oleh Budiasih (2014) dan Sari (2013). Disamping itu DER mempunyai pengaruh negatif pula terhadap nilai perusahaan seperti penelitian yang dilakukan oleh Nasehah (2012) dan Erawati \& Sukma (2014). Dengan demikian dapat dirumuskan hipotesis sebagai berikut:
H10: Return On Asset memediasi pengaruh DER terhadap nilai perusahaan

Berdasarkan pada telaah pustaka dan berbagai sumber penelitian terdahulu, kerangka pemikiran yang dikembangkan dalam penelitian ini adalah sebagai berikut:

Gambar 1

Kerangka Pemikiran Teoritis

"Analisis Pengaruh TATO, WCTO, dan DER terhadap Nilai Perusahaan dengan ROA sebagai Variabel Intervening”

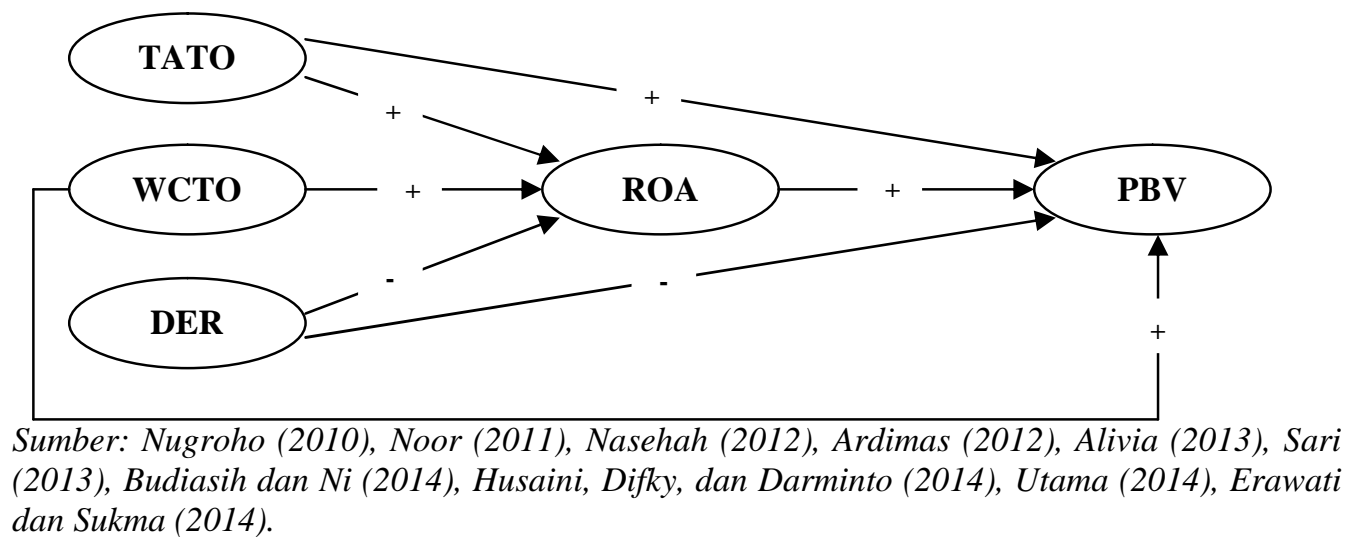

\section{METODE PENELITIAN}

\section{Populasi dan Sampel}

Populasi dalam penelitian ini adalah 155 perusahaan yang termasuk kedalam sektor manufaktur yang terdaftar di Bursa Efek Indonesia selama periode tahun 2013. Sampel penelitian ini sebanyak 64 perusahaan. Teknik pengambilan sampel dilakukan dengan metode purposive sampling. Adapun kriteria yang digunakan pada penelitian ini adalah sebagai berikut:

1. Perusahaan manufaktur yang terdaftar di BEI pada tahun 2013.

2. Perusahaan tersebut terdaftar secara terus-menerus di BEI selama tahun 2009-2013.

3. Perusahaan tersebut selalu memiliki nilai ROA yang positif selama tahun pengamatan.

4. Perusahaan tersebut memiliki nilai WCTO yang positif selama tahun pengamatan.
5. Perusahaan tersebut memiliki data lengkap yang dibutuhkan dalam penelitian.

\section{Metode Analisis}

Metode analisis data yang digunakan dalam penelitian ini adalah Analisis Jalur (Path Analysis) yang merupakan pengembangan dari model regresi. Dengan analisis jalur, persamaan regresi melibatkan variabel eksogen dan endogen serta dimungkinkan adanya pengujian terhadap variabel intervening. Analisis jalur juga dapat mengukur hubungan antar variabel dalam model baik secara langsung maupun tidak langsung. Model persamaan regresi yang digunakan adalah:

$$
\begin{aligned}
\text { ROA }= & \alpha_{0}+\beta_{1} \text { TATO }+\beta_{2} \text { WCTO }+\beta_{3} \\
& \text { DER }+e_{1} \\
\text { PBV }= & \alpha_{1}+\beta_{4} \text { TATO }+\beta_{5} \text { WCTO }+\beta_{6} \\
& \text { DER }+\beta_{7} \text { ROA }+e_{2}
\end{aligned}
$$


Keterangan:

$$
\begin{array}{ll}
\text { ROA } & \text { : Return On Asset } \\
\text { PBV } & \text { Price to Book Value } \\
\text { TATO : Total Asset Turnover } \\
\text { WCTO : Working Capital Turnover } \\
\text { DER } \quad \text { : Debt to Equity Ratio } \\
\beta_{1-7} \quad \text { : Beta Koefisien Regresi } \\
\mathrm{e}_{1-2} \quad \text { : Error of Term atau variabel } \\
\quad \text { pengganggu }
\end{array}
$$

\section{HASIL PENELITIAN DAN}

\section{PEMBAHASAN}

\section{Analisis Regresi Berganda}

Analisis regresi linier berganda bertujuan untuk mengetahui hubungan antara variabel independen dengan variabel dependen. Analisis regresi dalam penelitian ini untuk menguji pengaruh variabel TATO, WCTO, dan DER terhadap nilai perusahaan dengan menggunakan ROA sebagai variabel intervening.

\section{Uji Signifikansi Simultan (Uji} Statistik F)

Uji $F$ pada dasarnya menunjukkan apakah semua variabel independen yang dimasukkan dalam model mempunyai pengaruh secara bersama-sama terhadap variabel dependen (Ghozali, 2013).

Tabel 1

Hasil Uji F ROA

ANOVA $^{a}$

\begin{tabular}{rlrrrrr}
\hline Model & & Sum of Squares & Df & Mean Square & F & Sig. \\
\hline \multirow{2}{*}{1} & Regression & 2823.448 & 3 & 941.149 & 31.780 & $.000^{\mathrm{b}}$ \\
& Residual & 7966.271 & 269 & 29.614 & & \\
& Total & 10789.719 & 272 & & & \\
\hline
\end{tabular}

a. Dependent Variable: ROA

b. Predictors: (Constant), DER, TATO, WCTO

Sumber: data sekkunder yang diolah, 2015

Dari hasil perhitungan diperoleh nilai $F$ sebesar 31,780 dan nilai signifikansi sebesar 0,000 yang lebih kecil dari 0,05. Maka, dapat disimpulkan bahwa model memenuhi Goodness of Fit dan layak untuk digunakan.

Tabel 2

Hasil Uji F PBV

ANOVA ${ }^{\mathrm{a}}$

\begin{tabular}{rlrrrrr}
\hline Model & & Sum of Squares & Df & Mean Square & F & \multicolumn{1}{c}{ Sig. } \\
\hline \multirow{2}{*}{1} & Regression & 91.838 & 4 & 22.959 & 45.768 & $.000^{\mathrm{b}}$ \\
& Residual & 134.441 & 268 & .502 & & \\
& Total & 226.279 & 272 & & & \\
\hline
\end{tabular}

a. Dependent Variable: LnPBV

b. Predictors: (Constant), ROA, TATO, WCTO, DER

Sumber: data sekunder yang diolah, 2015

Dari hasil perhitungan diperoleh nilai $F$ sebesar 45,768 dan nilai signifikansi sebesar 0,000 yang lebih kecil dari 0,05. Maka, dapat disimpulkan bahwa model memenuhi Goodness of Fit dan layak untuk digunakan.

\section{Koefisien Determinasi $\left(\mathbf{R}^{2}\right)$}

Koefisien determinasi $\left(\mathrm{R}^{2}\right)$ pada intinya mengukur seberapa jauh kemampuan model dalam menerangkan variasi variabel dependen. Nilai $\left(R^{2}\right)$ yang mendekati satu berarti variabelvariabel independen memberikan hampir semua informasi yang dibutuhkan untuk 
Tabel 3

Koefisien Determinasi $\left(\mathbf{R}^{2}\right)$ ROA

Model Summary ${ }^{b}$

\begin{tabular}{lrrrrr}
\hline Model & $\mathrm{R}$ & R Square & $\begin{array}{c}\text { Adjusted R } \\
\text { Square }\end{array}$ & $\begin{array}{c}\text { Std. Error of the } \\
\text { Estimate }\end{array}$ & Durbin-Watson \\
\hline 1 & $.512^{\mathrm{a}}$ & .262 & .253 & 5.44191 & 2.034 \\
\hline
\end{tabular}

a. Predictors: (Constant), DER, TATO, WCTO

b. Dependent Variable: ROA

Sumber: data sekunder yang diolah, 2015

Nilai koefisien determinasi (adjusted $R^{2}$ ) sebesar 0,253 atau 25,3\% menunjukkan bahwa $25,3 \%$ variasi ROA dapat dijelaskan dengan variasi ketiga variabel bebas, yaitu TATO, WCTO, dan DER sedangkan selebihnya yakni sebesar $74,7 \%$ dijelaskan oleh variabel lain diluar model.

Tabel 4

Koefisien Determinasi $\left(\mathbf{R}^{2}\right)$ PBV Model Summary ${ }^{\mathrm{b}}$

$\begin{array}{lllll}\text { Model } & \mathrm{R} & \mathrm{R} \text { Square } & \text { Adjusted R } & \text { Std. Error of the Durbin-Watson }\end{array}$

\begin{tabular}{|c|c|c|c|c|c|}
\hline & & & & Estimate & \\
\hline 1 & $.637^{\mathrm{a}}$ & .406 & .397 & .70827 & 1.770 \\
\hline
\end{tabular}

a. Predictors: (Constant), ROA, TATO, WCTO, DER

b. Dependent Variable: LnPBV

Sumber: data sekunder yang diolah, 2015

Nilai koefisien determinasi (adjusted $R^{2}$ ) sebesar 0,397 atau 39,7\% menunjukkan bahwa $39,7 \%$ variasi PBV dapat dijelaskan dengan variasi ketiga variabel bebas, yaitu TATO, WCTO, DER, dan ROA sedangkan selebihnya yakni $60,3 \%$ dijelaskan oleh variabel lain diluar model.

\section{Uji Signifikansi Parsial (Uji t)}

Uji $t$ pada dasarnya menunjukkan seberapa jauh pengaruh variabel independen secara parsial dalam menerangkan variasi variabel dependen (Ghozali, 2013).

Tabel 5

Hasil Uji t ROA

Coefficients

\begin{tabular}{|c|c|c|c|c|c|c|c|c|}
\hline & \multirow[t]{2}{*}{ Model } & \multicolumn{2}{|c|}{$\begin{array}{l}\text { Unstandardized } \\
\text { Coefficients }\end{array}$} & \multirow{2}{*}{$\begin{array}{c}\text { Standardized } \\
\text { Coefficients }\end{array}$} & \multirow[t]{2}{*}{$\mathrm{T}$} & \multirow[t]{2}{*}{ Sig. } & \multicolumn{2}{|c|}{$\begin{array}{c}\text { Collinearity } \\
\text { Statistics }\end{array}$} \\
\hline & & B & $\begin{array}{l}\text { Std. } \\
\text { Error }\end{array}$ & & & & Tolerance & VIF \\
\hline \multirow{4}{*}{1} & (Constant) & 12.653 & 1.074 & & 11.778 & .000 & & \\
\hline & TATO & 2.347 & .753 & .167 & 3.117 & .002 & .952 & 1.050 \\
\hline & WCTO & -.173 & .078 & -.134 & -2.216 & .028 & .751 & 1.331 \\
\hline & DER & -6.252 & .860 & -.431 & -7.268 & .000 & .781 & 1.280 \\
\hline
\end{tabular}

a. Dependent Variable: ROA

Sumber: data sekunder yang diolah, 2015 
Berdasarkan tabel 5 diatas diperoleh persamaan regresi sebagai berikut:

ROA $=12,653+2,347$ TATO $-0,173$ WCTO - 6,252 DER

Berdasarkan persamaan regresi diatas, maka model regresi dapat dijelaskan sebagai berikut:

1. Nilai konstanta pada persamaan regresi sebesar 12,653 menunjukkan bahwa jika variabel independen dianggap konstan maka ROA akan mempunyai nilai sebesar 12,653 dengan tidak dipengaruhi oleh variabel-variabel independen.

2. Variabel TATO memiliki nilai koefisien regresi sebesar 2,347 dengan nilai signifikansi sebesar 0,002 (lebih kecil dari 0,05). Dengan demikian dapat disimpulkan bahwa TATO berpengaruh positif signifikan terhadap ROA. Hipotesis pertama yang menyebutkan TATO berpengaruh positif terhadap ROA diterima.

3. Variabel WCTO memiliki nilai koefisien regresi sebesar $-0,173$ dengan nilai signifikansi sebesar 0,028 (lebih kecil dari 0,05). Dengan demikian dapat disimpulkan bahwa WCTO berpengaruh negatif signifikan terhadap ROA. Hipotesis kedua yang menyebutkan WCTO berpengaruh positif terhadap ROA ditolak.

4. Variabel DER memiliki nilai koefisien regresi sebesar $-6,252$ dengan nilai signifikansi sebesar 0,000 (lebih kecil dari 0,05). Dengan demikian dapat disimpulkan bahwa DER berpengaruh negatif signifikan terhadap ROA. Hipotesis ketiga yang menyebutkan DER berpengaruh negatif terhadap ROA diterima.

Tabel 6

Hasil Uji t PBV

Coefficients $^{\mathrm{a}}$

\begin{tabular}{|c|c|c|c|c|c|c|c|c|}
\hline \multirow{2}{*}{\multicolumn{2}{|c|}{ Model }} & \multicolumn{2}{|c|}{$\begin{array}{l}\text { Unstandardized } \\
\text { Coefficients }\end{array}$} & \multirow{2}{*}{$\begin{array}{c}\text { Standardized } \\
\text { Coefficients }\end{array}$} & \multirow[t]{2}{*}{$\mathrm{T}$} & \multirow[t]{2}{*}{ Sig. } & \multicolumn{2}{|c|}{$\begin{array}{l}\text { Collinearity } \\
\text { Statistics }\end{array}$} \\
\hline & & B & $\begin{array}{l}\text { Std. } \\
\text { Error }\end{array}$ & & & & Tolerance & VIF \\
\hline \multirow{5}{*}{1} & (Constant) & -.865 & .172 & & -5.024 & .000 & & \\
\hline & TATO & .094 & .100 & .046 & .938 & .349 & .919 & 1.088 \\
\hline & WCTO & -.025 & .010 & -.134 & -2.438 & .015 & .738 & 1.356 \\
\hline & DER & .400 & .122 & .190 & 3.266 & .001 & .653 & 1.531 \\
\hline & ROA & .096 & .008 & .660 & 12.046 & .000 & .738 & 1.354 \\
\hline
\end{tabular}

a. Dependent Variable: LnPBV

Sumber: data sekunder yang diolah, 2015

Berdasarkan tabel 6 diatas diperoleh persamaan regresi sebagai berikut:

LnPBV $=0,865+0,094$ TATO $-0,025$ WCTO + 0,400 DER + 0,096 ROA

Berdasarkan persamaan regresi diatas, maka model regresi dapat dijelaskan sebagai berikut:
1. Nilai konstanta pada persamaan regresi sebesar 0,865 menunjukkan bahwa jika variabel independen dianggap konstan maka PBV akan mempunyai nilai sebesar 0,865 dengan tidak dipengaruhi oleh variabel-variabel independen.

2. Variabel TATO memiliki nilai koefisien regresi sebesar 0,094 
dengan nilai signifikansi sebesar 0,349 (lebih besar dari 0,05). Dengan demikian dapat disimpulkan bahwa TATO berpengaruh positif tidak signifikan terhadap PBV. Hipotesis keempat yang menyebutkan TATO berpengaruh positif terhadap PBV ditolak.

3. Variabel WCTO memiliki nilai koefisien regresi sebesar $-0,025$ dengan nilai signifikansi sebesar 0,015 (lebih kecil dari 0,05). Dengan demikian dapat disimpulkan bahwa WCTO berpengaruh negatif signifikan terhadap PBV. Hipotesis kelima yang menyebutkan WCTO berpengaruh positif terhadap PBV ditolak.

4. Variabel DER memiliki nilai koefisien regresi sebesar 0,400 dengan nilai signifikansi sebesar 0,001 (lebih kecil dari 0,05). Dengan demikian dapat disimpulkan bahwa DER berpengaruh positif signifikan terhadap PBV. Hipotesis keenam yang menyebutkan DER berpengaruh negatif terhadap PBV ditolak.

5. Variabel ROA memiliki nilai koefisien regresi sebesar 0,096 dengan nilai signifikansi sebesar 0,000 (lebih kecil dari 0,05). Dengan demikian dapat disimpulkan bahwa ROA berpengaruh positif signifikan terhadap PBV. Hipotesis ketujuh yang menyebutkan ROA berpengaruh positif terhadap PBV diterima.

Analisis Jalur

Analisis jalur dilakukan untuk menganalisis kekuatan konstruk variabel, baik pengaruh langsung, tidak langsung, dan pengaruh total variabel eksogen terhadap variabel endogen. Disamping itu, analisis jalur juga bertujuan untuk mengetahui hubungan kausalitas variabel eksogen terhadap variabel endogen secara menyeluruh. Berdasarkan hasil analisis pengaruh langsung, tidak langsung, dan pengaruh total maka model analisis jalur dapat digambarkan sebagai berikut:

Gambar 2

Model Analisis Jalur TATO terhadap PBV

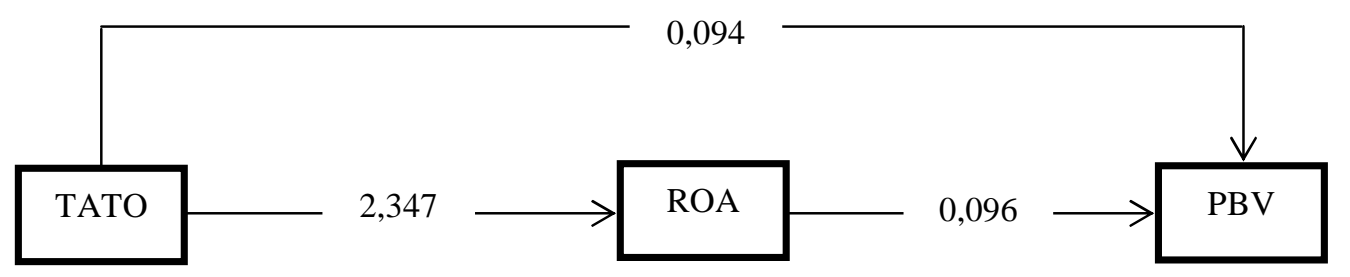

Gambar 2 menunjukkan bahwa TATO berpengaruh langsung terhadap PBV sebesar 0,094 dan berpengaruh tidak langsung terhadap PBV sebesar $0,225312 \quad(2,347 \quad \mathrm{x} \quad 0,096)$. Total pengaruh TATO terhadap PBV $=0,094$
$+0,225312=0,319312$. Besarnya koefisien pengaruh tidak langsung yang lebih besar daripada koefisien pengaruh langsung, maka dapat disimpulkan bahwa ROA memediasi pengaruh TATO terhadap PBV. 


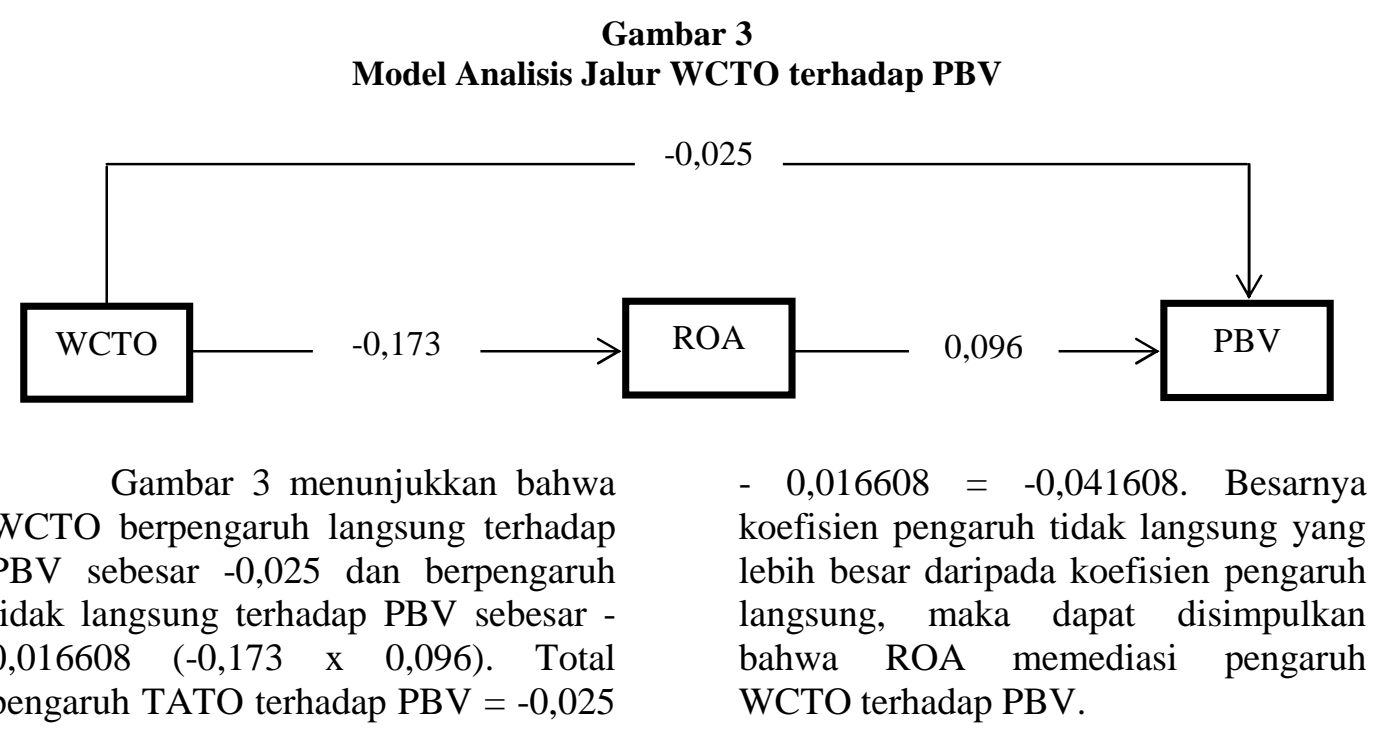

Gambar 4

Model Analisis Jalur DER terhadap PBV

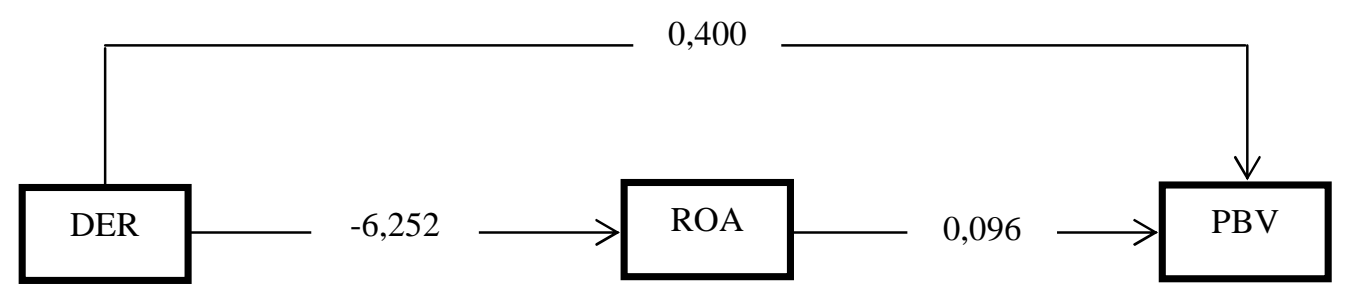

Gambar 4 menunjukkan bahwa DER berpengaruh langsung terhadap PBV sebesar 0,400 dan berpengaruh tidak langsung terhadap PBV sebesar 0,600192 (-6,252 x 0,096). Total pengaruh DER terhadap PBV $=0,400$ $0,600192=-0,200192$. Besarnya koefisien pengaruh tidak langsung yang lebih kecil daripada koefisien pengaruh langsung, maka dapat disimpulkan bahwa ROA tidak memediasi pengaruh DER terhadap PBV.

Sobel Test

Sobel Test digunakan untuk lebih memastikan hubungan langsung dan tidak langsung antara variabel independen terhadap variabel dependen melalui variabel intervening. Adapun langkah-langkah yang harus dilakukan untuk menguji pengaruh tidak langsung menggunakan sobel test adalah sebagai berikut:
1. Hitung standard error dari koefisien tidak langsung (indirect effect) dengan menggunakan rumus:

$$
\begin{aligned}
& S_{p 2 p 3}=\sqrt{p 3^{2} S p 2^{2}+p 2^{2} S p 3^{2}+S p 2^{2} S p 3^{2}} \\
& \text { dimana, } \\
& \mathrm{S}_{\mathrm{p} 2 \mathrm{p} 3}=\text { Standard error koefisien } \\
& \text { indirect effect } \\
& \text { p2 = Koefisien regresi pada kolom } \\
& \text { unstandardized coefficients } \\
& \text { untuk pengaruh TATO } \\
& \text { terhadap ROA } \\
& \text { p3 = Koefisien regresi pada kolom } \\
& \text { unstandardized coefficients } \\
& \text { untuk pengaruh ROA } \\
& \text { terhadap PBV } \\
& \text { Sp2 = Standard error pada kolom } \\
& \text { unstandardized untuk } \\
& \text { pengaruh TATO terhadap } \\
& \text { ROA } \\
& \text { Sp3 = Standard error pada kolom } \\
& \text { unstandardized untuk } \\
& \text { pengaruh ROA terhadap } \\
& \text { PBV }
\end{aligned}
$$


2. Setelah melakukan perhitungan $\left(S_{\mathrm{p} 2 \mathrm{p3} 3}\right)$, selanjutnya dapat dihitung nilai $t$ statistik dari koefisien pengaruh mediasi tersebut dengan rumus sebagai berikut:

$$
t=\frac{p 2 p 3}{S p 2 p 3}
$$

3. Setelah mengetahui nilai $\mathrm{t}$ statistik pengaruh mediasi, bandingkan nilai t hitung dengan $t$ tabel. Jika t hitung lebih besar daripada t tabel, maka variabel intervening dapat memediasi pengaruh variabel independen terhadap variabel dependen.

Gambar 5

Hasil Sobel Test

\begin{tabular}{ccc}
\hline Keterangan & t hitung & t tabel \\
\hline $\mathrm{TATO} \rightarrow \mathrm{ROA} \rightarrow \mathrm{PBV}$ & 3,00697 & 1,96 \\
$\mathrm{WCTO} \rightarrow \mathrm{ROA} \rightarrow \mathrm{PBV}$ & $-2,17382$ & 1,96 \\
$\mathrm{DER} \rightarrow \mathrm{ROA} \rightarrow \mathrm{PBV}$ & $-6,20225$ & 1,96 \\
\hline
\end{tabular}

Berdasarkan hasil Sobel Test, diketahui bahwa untuk pengaruh TATO terhadap PBV melalui ROA, t hitung lebih besar daripada t tabel $(3,00697>$ 1,96). Untuk pengaruh WCTO terhadap PBV melalui ROA, $t$ hitung lebih kecil daripada t tabel $(-2,17382<1,96)$. Dan untuk pengaruh DER terhadap PBV melalui ROA, $t$ hitung lebih kecil daripada t tabel $(-6,20225<1,96)$. Hasil uji sobel test ini sesuai dengan hasil pengujian sebelumnya bahwa ROA dapat memediasi pengaruh TATO terhadap PBV tetapi ROA tidak dapat memediasi pengaruh DER terhadap PBV. Namun, uji Sobel Test ini tidak sesuai dengan hasil pengujian sebelumnya yang menyatakan bahwa ROA dapat memediasi pengaruh WCTO terhadap PBV. Tetapi dengan uji Sobel Test diketahui bahwa ROA tidak dapat digunakan sebagai variabel mediasi antara variabel WCTO dan PBV.

\section{Pembahasan Hasil Penelitian}

\section{Pengujian Hipotesis 1}

Hipotesis pertama pada penelitian ini adalah Total Asset Turnover (TATO) berpengaruh positif terhadap Return On Asset (ROA). Berdasarkan hasil uji statistik diperoleh koefisien regresi sebesar 2,347 dengan nilai signifikansi sebesar 0,002 yang lebih kecil dari 0,05. Berdasarkan hasil tersebut dapat disimpulkan bahwa TATO berpengaruh positif dan signifikan terhadap ROA. Sehingga hipotesis pertama dapat diterima.

Berdasarkan pengujian hipotesis pertama yang menyatakan bahwa TATO berpengaruh positif terhadap ROA, maka dapat dikatakan bahwa peningkatan nilai TATO dapat meningkatkan nilai ROA perusahaan. Peningkatan nilai TATO menunjukkan bahwa perusahaan semakin efisien dalam menggunakan seluruh aset dalam menghasilkan laba. Meningkatnya laba perusahaan akan berdampak pada peningkatan nilai ROA.

Hasil penelitian ini sesuai dengan penelitian yang dilakukan oleh Noor (2011), Sari (2013), dan Budiasih \& Ni (2014) yang menyatakan TATO memiliki pengaruh positif signifikan terhadap ROA.

\section{Pengujian Hipotesis 2}

Hipotesis kedua pada penelitian ini adalah Working Capital Turnover (WCTO) berpengaruh positif terhadap Return On Asset (ROA). Berdasarkan hasil uji statistik diperoleh koefisien regresi sebesar $-0,173$ dengan nilai signifikansi sebesar 0,028 yang lebih kecil dari 0,05. Berdasarkan hasil tersebut dapat disimpulkan bahwa WCTO berpengaruh negatif dan signifikan terhadap ROA. Sehingga hipotesis kedua tidak dapat diterima.

Berdasarkan pengujian hipotesis kedua yang menyatakan bahwa WCTO 
berpengaruh negatif terhadap ROA, maka dapat dikatakan bahwa peningkatan nilai WCTO dapat menurunkan nilai ROA perusahaan. Penjualan sangat tinggi dalam posisi modal kerja yang sangat kecil. Hal ini memiliki arti bahwa pengelolaan manajemen modal kerja yang sangat agresif dengan menekan investasi modal kerja yang sangat kecil. Sehingga dalam kondisi ini profitabilitas yang dicapai tidak dapat optimal. Dengan demikian, perputaran modal kerja yang tinggi justru menurunkan profitabilitas.

Hasil penelitian ini sesuai dengan penelitian yang dilakukan oleh Noor (2011)dan Arif (2015) yang menyatakan WCTO memiliki pengaruh negatif signifikan terhadap ROA.

\section{Pengujian Hipotesis 3}

Hipotesis ketiga pada penelitian ini adalah Debt to Equity Ratio (DER) berpengaruh negatif terhadap Return On Asset (ROA). Berdasarkan hasil uji statistik diperoleh koefisien regresi sebesar $-6,252$ dengan nilai signifikansi sebesar 0,000 yang lebih kecil dari 0,05. Berdasarkan hasil tersebut dapat disimpulkan bahwa DER berpengaruh negatif dan signifikan terhadap ROA. Sehingga hipotesis ketiga dapat diterima.

Berdasarkan pengujian hipotesis ketiga yang menyatakan bahwa DER berpengaruh negatif terhadap ROA, maka dapat dikatakan bahwa peningkatan nilai DER dapat menurunkan nilai ROA perusahaan. Penggunaan hutang yang tinggi akan berdampak pada penurunan profitabilitas perusahaan karena beban bunga yang ditanggung perusahaan juga semakin tinggi yang berakibat pada penurunan nilai ROA.

Hasil penelitian ini sesuai dengan penelitian yang dilakukan oleh Sari (2013), Utama (2014), dan Budiasih \& $\mathrm{Ni}$ (2014) yang menyatakan DER memiliki pengaruh negatif signifikan terhadap ROA.

\section{Pengujian Hipotesis 4}

Hipotesis keempat pada penelitian ini adalah Total Asset Turnover (TATO) berpengaruh positif terhadap Price to Book Value (PBV). Berdasarkan hasil uji statistik diperoleh koefisien regresi sebesar 0,094 dengan nilai signifikansi sebesar 0,349 yang lebih besar dari 0,05. Berdasarkan hasil tersebut dapat disimpulkan bahwa TATO berpengaruh positif dan tidak signifikan terhadap PBV. Sehingga hipotesis keempat tidak dapat diterima.

Berdasarkan pengujian hipotesis keempat yang menyatakan bahwa TATO berpengaruh positif terhadap PBV, maka dapat dikatakan bahwa peningkatan nilai TATO dapat meningkatkan nilai PBV perusahaan. Semakin tinggi TATO maka kemampuan perusahaan dalam mengelola aset perusahaan untuk memperoleh penjualan semakin tinggi. Pengelolaan aset perusahaan yang efisien akan meningkatkan nilai perusahaan.

Hasil penelitian ini sesuai dengan penelitian yang dilakukan oleh Alivia (2013) yang menyatakan TATO memiliki pengaruh positif tidak signifikan terhadap PBV.

\section{Pengujian Hipotesis 5}

Hipotesis kelima pada penelitian ini adalah Working Capital Turnover (WCTO) berpengaruh positif terhadap Price to Book Value (PBV). Berdasarkan hasil uji statistik diperoleh koefisien regresi sebesar $-0,025$ dengan nilai signifikansi sebesar 0,015 yang lebih kecil dari 0,05. Berdasarkan hasil tersebut dapat disimpulkan bahwa WCTO berpengaruh negatif dan signifikan terhadap PBV. Sehingga hipotesis kelima tidak dapat diterima.

Berdasarkan pengujian hipotesis kelima yang menyatakan bahwa WCTO berpengaruh negatif terhadap PBV, maka dapat dikatakan bahwa peningkatan nilai WCTO dapat menurunkan nilai PBV perusahaan. 
Pengelolaan manajemen modal kerja yang terlalu agresif mengakibatkan sangat rendahnya investasi modal kerja dalam mencapai tingkat penjualan tertentu. Sehingga dalam kondisi ini menyebabkan penjualan yang dicapai tidak dapat optimal. Penjualan yang tidak optimal dapat menyebabkan turunnya profitabillitas perusahaan yang menunjukkan kurang baiknya kinerja perusahaan yang berdampak pada menurunnya nilai perusahaan.

\section{Pengujian Hipotesis 6}

Hipotesis keenam pada penelitian ini adalah Debt to Equity Ratio (DER) berpengaruh negatif terhadap Price to Book Value (PBV). Berdasarkan hasil uji statistik diperoleh koefisien regresi sebesar 0,400 dengan nilai signifikansi sebesar 0,001 yang lebih kecil dari 0,05. Berdasarkan hasil tersebut dapat disimpulkan bahwa DER berpengaruh positif dan signifikan terhadap PBV. Sehingga hipotesis keenam tidak dapat diterima.

Berdasarkan pengujian hipotesis keenam yang menyatakan bahwa DER berpengaruh positif terhadap PBV, maka dapat dikatakan bahwa peningkatan nilai DER dapat meningkatkan nilai PBV perusahaan. Penggunaan hutang sebagai sumber pembiayaan dapat menjadi sinyal positif bagi investor dan mampu meningkatkan nilai perusahaan. Perusahaan dengan prospek yang baik lebih memilih pendanaan dengan menggunakan hutang daripada menerbitkan saham baru. Hal ini karena pendanaan dengan hutang tidak akan menurunkan return bagi investor selama manfaat hutang lebih besar daripada beban yang ditimbulkan.

Hasil penelitian ini sesuai dengan penelitian yang dilakukan oleh Marlina (2013) dan Sari (2013) yang menyatakan DER memiliki pengaruh positif signifikan terhadap PBV.

\section{Pengujian Hipotesis 7}

Hipotesis ketujuh pada penelitian ini adalah Return On Asset
(ROA) berpengaruh positif terhadap Price to Book Value (PBV). Berdasarkan hasil uji statistik diperoleh koefisien regresi sebesar 0,096 dengan nilai signifikansi sebesar 0,000 yang lebih kecil dari 0,05. Berdasarkan hasil tersebut dapat disimpulkan bahwa ROA berpengaruh positif dan signifikan terhadap PBV. Sehingga hipotesis ketujuh dapat diterima.

Berdasarkan pengujian hipotesis ketujuh yang menyatakan bahwa ROA berpengaruh positif terhadap PBV, maka dapat dikatakan bahwa peningkatan nilai ROA dapat meningkatkan nilai PBV perusahaan. Meningkatnya ROA akan meningkatkan nilai perusahaan. Semakin tinggi profitabilitas menunjukkan bahwa semakin baik kinerja perusahaan. Kinerja perusahaan yang semakin baik, maka nilai perusahaan pun juga akan meningkat.

Hasil penelitian ini sesuai dengan penelitian yang dilakukan oleh Alivia (2013) dan Sari (2013) yang menyatakan ROA memiliki pengaruh positif signifikan terhadap PBV.

\section{Pengujian Hipotesis 8}

Hasil pengujian hipotesis ini menunjukkan bahwa Total Asset Turnover (TATO) berpengaruh langsung terhadap Price to Book Value (PBV) sebesar 0,094 dan Total Asset Turnover (TATO) berpengaruh tidak langsung terhadap Price to Book Value (PBV) sebesar 0,225312. Besarnya koefisien pengaruh langsung lebih kecil daripada koefisien pengaruh tidak langsung. Selain itu, berdasarkan hasil Sobel Test nilai $\mathrm{t}$ hitung lebih besar daripada nilai $\mathrm{t}$ tabel $(3,00697>1,96)$. Dengan demikian, dapat disimpulkan bahwa ROA memediasi pengaruh antara TATO dan PBV. Sehingga hipotesis kedelapan dapat diterima.

\section{Pengujian Hipotesis 9}

Hasil pengujian hipotesis ini menunjukkan bahwa Working Capital Turnover (WCTO) berpengaruh langsung terhadap Price to Book Value 
(PBV) sebesar -0,025 dan Working Capital Turnover (WCTO) berpengaruh tidak langsung terhadap Price to Book Value (PBV) sebesar -0,016608. Besarnya koefisien pengaruh langsung lebih kecil daripada koefisien pengaruh tidak langsung. Tetapi, berdasarkan hasil Sobel Test nilai $\mathrm{t}$ hitung lebih kecil daripada nilai $t$ tabel $(-2,17382<1,96)$. Dengan demikian, dapat disimpulkan bahwa ROA tidak memediasi pengaruh antara WCTO dan PBV. Sehingga hipotesis kesembilan tidak dapat diterima.

\section{Pengujian Hipotesis 10}

Hasil pengujian hipotesis ini menunjukkan bahwa Debt to Equity Ratio (DER) berpengaruh langsung terhadap Price to Book Value (PBV) sebesar 0,400 dan Debt to Equity Ratio (DER) berpengaruh tidak langsung terhadap Price to Book Value (PBV) sebesar -0,600192. Besarnya koefisien pengaruh langsung lebih besar daripada koefisien pengaruh tidak langsung. Selain itu, berdasarkan hasil Sobel Test nilai $\mathrm{t}$ hitung lebih kecil daripada nilai $\mathrm{t}$ tabel $(-6,20225<1,96)$. Dengan demikian, dapat disimpulkan bahwa ROA tidak memediasi pengaruh antara DER dan PBV. Sehingga hipotesis kesepuluh tidak dapat diterima.

\section{KESIMPULAN}

Berdasarkan hasil analisis data dan pembahasan yang telah dijabarkan maka dapat diambil kesimpulan bahwa variabel Return On Asset (ROA) dapat dijelaskan oleh variabel Total Asset Turnover (TATO), Working Capital Turnover (WCTO), dan Debt to Equity Ratio (DER) sebesar 25,3\%, sementara sisanya sebesar $74,7 \%$ dijelaskan oleh variabel-variabel lain diluar model. Sedangkan variabel Price to Book Value (PBV) dapat dijelaskan oleh variabel Total Asset Turnover (TATO), Working Capital Turnover (WCTO), Debt to Equity Ratio (DER), dan Return On Asset (ROA) sebesar 39,7\%, sementara sisanya sebesar $60,3 \%$ dijelaskan oleh variabel-variabel lain diluar model.

Berdasarkan hasil pengujian yang telah dilakukan dapat diketahui bahwa TATO berpengaruh positif signifikan terhadap ROA. Sedangkan WCTO dan DER berpengaruh negatif signifikan terhadap ROA. Variabel TATO berpengaruh positif tidak signifikan terhadap PBV. Variabel WCTO berpengaruh negatif signifikan terhadap PBV. Variabel DER dan ROA berpengaruh positif signifikan terhadap PBV. Berdasarkan analisis jalur dan Sobel Test maka dapat disimpulkan bahwa ROA memediasi pengaruh TATO terhadap PBV. Tetapi, ROA tidak memediasi pengaruh WCTO dan DER terhadap ROA.

$$
\text { Penelitian ini memiliki }
$$

keterbatasan, yaitu sampel yang digunakan sebanyak 64 perusahaan manufaktur yang memenuhi kriteria sampel dari 155 perusahaan manufaktur go public yang tercatat di BEI. Variabel yang digunakan hanya sebatas pada TATO, WCTO, dan DER dengan ROA sebagai variabel intervening. Selanjutnya adalah tahun pengamatan yang hanya terbatas antara tahun 20092013.

Sebagai saran bagi perusahaan, diharapkan dapat memperhatikan variabel DER untuk pengaruhnya terhadap ROA. Karena besarnya jumlah hutang akan mempengaruhi profitabilitas yang dicapai disebabkan semakin besarnya kewajiban yang ditanggung perusahaan. Selanjutnya adalah variabel TATO karena aset perusahaan harus dapat digunakan sebaik mungkin untuk menghindari terjadinya dana menganggur. Untuk para investor, variabel ROA menjadi yang paling berpengaruh terhadap nilai perusahaan. Peningkatan profitabilitas menunjukkan prospek perusahaan yang semakin baik dan dapat memberikan kemakmuran bagi pemegang saham. Serta untuk penelitian selanjutnya dapat 
digunakan variabel-variabel lain yang berpengaruh terhadap PBV dan menggunakan variabel intervening lain yang lebih dapat memediasi pengaruh variabel independen terhadap variabel PBV.

\section{REFERENSI}

Agustina, Laras Ayu Aditya. 2014. "Pengaruh CAR, NPL, NIM, LDR, dan BOPO terhadap Nilai Perusahaan dengan ROA sebagai Variabel Intervening pada Bank-bank Umum Go Public di Indonesia Periode 2008-2012". Skripsi. Universitas Diponegoro.

Alivia, Natasha Rizky. 2013. "Analisis Faktor-faktor yang Mempengaruhi Nilai Perusahaan dengan Profitabilitas sebagai Variabel Intervening (Studi pada Perusahaan Manufaktur yang Listed di BEI Tahun 2008-2011)". Diponegoro Journal of Management Vol. 2 No. 2 Hal 1-12.

Ardimas, Wahyu. 2012. "Pengaruh Kinerja Keuangan dan Corporate Social Responsibility (CSR) terhadap Nilai Perusahaan pada Bank Go Public yang Terdaftar di BEI'. Skripsi. Universitas Gunadarma.

Arif, Syaiful; Zahroh Z.A; Raden Rustam Hidayat. 2015. "Pengaruh Perputaran Modal Kerja, Leverage, dan Pertumbuhan Penjualan terhadap Profitabilitas (Studi pada Perusahaan Makanan dan Minuman yang Terdaftar di Bursa Efek Indonesia pada Tahun 2011-2013)". Jurnal Administrasi Bisnis (JAB) Vol. 27 No. 1.

Brigham, Eugene F. dan Joel F. Houston. 2011. "Dasar-dasar Manajemen Keuangan II Edisi 11". Jakarta: Salemba Empat.

Budiasih, I G.A.N. dan Ni Made Vironika Sari. 2014. "Pengaruh Debt to Equity Ratio, Firm Size, Inventory Turnover, dan Asset Turnover pada Profitabilitas". EJurnal Akuntansi Universitas Udayana 6.2: 261-273.

Carningsih. 2012. "Pengaruh Good Corporate Governance terhadap Hubungan antara Kinerja Keuangan dengan Nilai Perusahaan (Studi Kasus pada Perusahaan Property dan Real Estate yang Terdaftar di Bursa Efek Indonesia". Skripsi. Universitas Gunadarma.

Erawati, Teguh dan Sukma Mindra. 2014. "Pengaruh Earning Per Share (EPS), Ukuran Perusahaan, Profitabilitas, dan Leverage terhadap Nilai Perusahaan (Studi Kasus pada Perusahaan Manufaktur yang Terdaftar di Bursa Efek Indonesia pada Tahun 2009-2011)". Jurnal Akuntansi Vol. 2 No. 2 Hal 10-22.

Ghozali, Imam. 2011. "Aplikasi Analisis Multivariate dengan Program IBM SPSS 19". Semarang: Badan Penerbit Universitas Diponegoro.

Ghozali, Imam. 2013. "Aplikasi Analisis Multivariate dengan Program IBM SPSS 21". Semarang: Badan Penerbit Universitas Diponegoro.

Husaini, Ahmad; Difky Mashady; Darminto. 2014. "Pengaruh Working Capital Turnover (WCT), Current Ratio (CR), dan Debt to Total Asset (DTA) terhadap Return On Investment (ROI) (Studi pada Perusahaan Farmasi yang Terdaftar di Bursa Efek Indonesia Tahun 2009-2012)". Jurnal Administrasi Bisnis (JAB) Vol. 7 No. 1.

Husnan, Suad dan Enny Pudjiastuti. 2002. "Dasar-dasar Manajemen Keuangan Edisi Keempat". Yogyakarta: UPP AMP YKPN.

Marlina, Tri. 2013. "Pengaruh Earning Per Share, Return On Equity, Debt to Equity Ratio, dan Size terhadap Price to Book Value". Jurnal Ilmiah Akuntansi Kesatuan (JIAKES) Vol. 1 No. 1 pg. 59-72. 
Martono dan Agus Harjito. 2008. "Manajemen Keuangan". Yogyakarta: Ekonisia Yogyakarta.

Munawir. 1993. "Analisa Laporan Keuangan". Yogyakarta: Liberty.

Nasehah, Durrotun. 2012. "Analisis Pengaruh ROE, DER, DPR, Growth, dan Firm Size terhadap Price to Book Value (Studi Kasus pada Perusahaan Manufaktur yang Listed di BEI Periode Tahun 2007-2010". Diponegoro Journal of Management Vol. 1 No. 1 Hal. 1-9.

Nugroho, Elfianto. 2011. "Analisis Pengaruh Likuiditas, Pertumbuhan Penjualan, Perputaran Modal Kerja, Ukuran Perusahaan, dan Leverage terhadap Profitabilitas Perusahaan". Skripsi. Universitas Diponegoro.

Noor, Akhmad Syafrudin. 2011. "Analisis Faktor-faktor yang Mempengaruhi Kinerja Keuangan Perusahaan Telekomunikasi yang Go Public d Bursa Efek Indonesia". Jurnal Manajemen dan Akuntansi Vol. 12 No. 1 April 2011.

Rahmawati, Fitri Linda. 2012. "Pengaruh Current Ratio, Inventory Turnover, dan Debt to Equity Ratio terhadap Return On Assets (Studi pada Perusahaan Food and Beverage yang Listing di Bursa Efek Indonesia Tahun 2007-2009)". Skripsi. Universitas Negeri Malang.

Riyanto, Bambang. 2011. "Dasar-dasar Pembelanjaan Perusahaan". Yogyakarta: BPFE.

Salvatore, Dominick. 2005. "Ekonomi Manajerial dalam Perekonomian Global Edisi 5". Jakarta: Salemba Empat.

Sari, Novia Maharani Yuliana Dewi Putri Sari. 2013. "Analisis Pengaruh Leverage, Efektivitas Aset, dan Sales terhadap Profitabilitas serta Dampaknya terhadap Nilai Perusahaan". Diponegoro Journal of Management Vol. 2 No. 3 Hal 1-13.

Sudana, I Made. 2011. "Manajemen Keuangan Perusahaan". Jakarta: Erlangga.

Sulistyawan, Junus. 2005. "Analisis Pengaruh Indeks Laporan Keuangan dan Rasiorasio Keuangan terhadap Corporate Performance". Tesis. Universitas Diponegoro.

Ulupui, I.G.K.A. 2007. “Analisis Pengaruh Rasio Likuiditas, Leverage, Aktivitas, dan Profitabilitas terhadap Return Saham". Jurnal Akuntansi Fakultas Ekonomi. Universitas Udayana.

Utama, Alfarizi Cahya. 2014. "Pengaruh Current Ratio, Debt Equity Ratio, Debt Asset Ratio, dan Perputaran Modal Kerja terhadap Return On Asset pada Perusahaan Manufaktur yang Terdaftar di Bursa Efek Indonesia Tahun 20102012”. Semarang: Diponegoro Journal of Accounting Vol. 03 No. 02 Hal. 1-13.

Weston, J. F. dan Copeland T.E. 1999. "Manajemen Keuangan Edisi 9". Jakarta: Binarupa Aksara.

Weston, J. Fred dan Eugene F. Brigham. 1998. "Dasar-dasar Manajemen Keuangan". Jakarta: Penerbit Erlangga. 